\title{
Mycoremediation of vinasse by surface response methodology and preliminary studies in air-lift bioreactors
}

\author{
Moniky S. Aragão a , Diego B. Menezes a, Larissa C. Ramos ${ }^{\text {b, c }}$, Helon S. Oliveira a

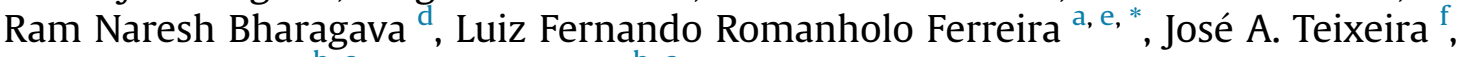 \\ Denise S. Ruzene ${ }^{\mathrm{b}, \mathrm{c}}$, Daniel P. Silva ${ }^{\mathrm{b}, \mathrm{c}}$ \\ a Institute of Technology and Research, Murilo Dantas Avenue 300, Campus Farolândia, 49032-490, Aracaju, SE, Brazil \\ ${ }^{\mathrm{b}}$ Northeastern Biotechnology Network - RENORBIO, Federal University of Sergipe, 49100-000, São Cristóvão, Sergipe, Brazil \\ ' Center for Exact Sciences and Technology, Federal University of Sergipe, 49100-000, São Cristóvão, SE, Brazil \\ ${ }^{\mathrm{d}}$ Laboratory for Bioremediation and Metagenomics Research (LBMR), Department of Microbiology (DM), Babasaheb Bhimrao Ambedkar University (A \\ Central University), Vidya Vihar, Raebareli Road, Lucknow, 226 025, Uttar Pradesh, India \\ e Graduate Program in Process Engineering, Tiradentes University, Murilo Dantas Avenue, 300, Farolândia, 49032-490, Aracaju, Sergipe, Brazil \\ ${ }^{\mathrm{f}}$ Centre of Biological Engineering, University of Minho, Campus Gualtar, 4710-057, Braga, Portugal
}

\section{H I G H L I G H T S}

- Pleurotus sajor-caju exhibited high degradation potential of vinasse.

- Air-lift bioreactors had a good performance and may be used in scaleup studies.

- Different configurations of the bioreactor affect the efficiency of the process.

- P. sajor-caju presented high capacity for the production of enzymes and biomass when cultivated in vinasse.

\section{A R T I C L E I N F O}

\section{Article history:}

Received 10 July 2019

Received in revised form

11 October 2019

Accepted 20 November 2019

Available online 25 November 2019

Handling Editor: A. Adalberto Noyola

\section{Keywords:}

Sugarcane vinasse

Biodegradation

Decolorization

Fungal biomass

Air-lift bioreactor

Ligninolytic enzymes
G R A P H I C A L A B S T R A C T

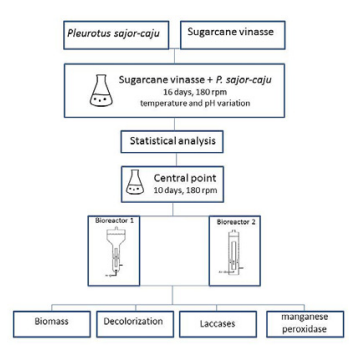

\footnotetext{
* Corresponding author. Graduate Program in Process Engineering, Tiradentes University, Murilo Dantas Avenue, 300, Farolândia, 49032-490, Aracaju, Sergipe, Brazil.

E-mail address: luiz.romanholo@pq.cnpq.br (L.F. Romanholo Ferreira).
} 
possible to emphasize that different configurations in the bioreactor can affect the efficiency of the process.

() 2019 Elsevier Ltd. All rights reserved.

\section{Introduction}

In view of the widespread contamination of the environment by persistent and toxic chemical pollutants from industrial wastewater, it is essential to develop economical methods for their remediation. One of the major problems of the sugar and alcohol industries is the large volume of waste generated, mainly vinasse, which represents a potential pollutant when inadequately administered (Ferreira et al., 2010; Colin et al., 2016; Souza et al., 2016; Hoarau et al., 2018). Sugarcane vinasse is an effluent that can present variation in its composition, depending on the raw material used and the process used in the distillation of ethanol. It consists basically of water and non-volatile components of the fermentation broth, yielding 8-18 L of vinasse per liter of alcohol produced (Krzywonos and Seruga, 2012; Colin et al., 2016; Vilar et al., 2018).

Due to its composition, vinasse has been applied in the agricultural sector as fertilizer, mainly in sugarcane crops. Vinasse contains $94 \%-97 \%$ water and a large amount of inorganic and organic matters, such as potassium, phosphorus, sulfate, calcium and magnesium. It is also characterized by a low $\mathrm{pH}$ (4.5-4.8), with a typical odor and dark brown color, due to the presence of melanoidins, organic compounds formed by the Maillard reaction, which occurs from the interaction between a reducing sugar and amino acid. This compound is used by fungi as a carbon source for their growth, which, as a result, can act in the mineralization and immobilization of nitrogen promoting processes of nitrification, denitrification and biological fixation (González et al., 2008; Ferreira et al., 2010; Seruga and Krzywonos, 2015; Guerreiro et al., 2016; Queiroga et al., 2018; Hoarau et al., 2018).

Brazilian sugarcane industries have been struggling to deal with the irregular disposal of vinasse promoting advances in biotechnology and environmental concern, both aiming to improve the use of vinasse. Current studies seek to emphasize on the use of compounds (minerals, phenolic compounds, anthocyanins, tannins and furfurans) contained in the effluent, and the reduction of polluting potential and the final volume of production. This has focused companies' attention on the development of waste treatment systems that promote low-cost mineralization and decolorization of vinasse and other effluents. Considering all these aspects, the use of microorganisms is very promising due to their potential for bioremediation associated with their ligninolytic enzymes and the production of valuable biomass (Moraes et al., 2015; Santal et al., 2016; Krzywonos et al., 2017; Tostain et al., 2018).

The genus Pleurotus represents a diverse group of ligninolytic fungi, which includes mushrooms of high nutritional value, therapeutic properties and diverse environmental and biotechnological applications (Silveira et al., 2015; Corrêa et al., 2016; Finimundy et al., 2018). The species Pleurotus sajor-caju is a basidiomycete capable of secreting enzymes to hydrolyse polymers into smaller valuable molecules. The ligninolytic Pleurotus fungi and its complex hydrolysis enzymes, is used in a variety of applications such as bioconversion of agricultural residues into organic compounds used for animal feed using specific enzymes for the biodegradation of pollutants, xenobiotics and industrial contaminants as well as antimicrobial agents, as can be seen in several current publications (Chanakya et al., 2015; Rouches et al., 2016; Tarhan and Tongul,
2017; Owaid et al., 2017). In addition, P. sajor-caju presents better biodegradability of vinasse when compared to other fungi of white rot (Ferreira et al., 2010, 2011).

In the enzymatic complex of fungi belonging to the white rot group can be identified ligninolytic enzymes, which include phenoloxidases such as manganese peroxidase (MnP; EC 1.11.1.13) and laccase (Lac; EC 1.10.3.2) (Liu et al., 2009; Menezes et al., 2017; Paramjeet et al., 2018). Laccases are multi-copper enzymes, capable of oxidizing phenolic compounds, reducing oxygen to water by removing an electron from the aromatic substrate, producing phenoxyl radicals. As these enzymes catalyze the oxidation of many phenolic and aromatic amines, laccase-mediated reactions have become a promising alternative for remediation of environmental pollutants (Calvo et al., 1998; Munari et al., 2008 Alcalde, 2015; Menezes et al., 2017; Voběrková et al., 2018).

Although there are numerous applications for the P. sajor-caju enzyme system, its use in the treatment of industrial effluents, such as vinasse, has been tested only in agitation methods, limiting the ability of microorganisms to activity (Borja et al., 1993; Rodríguez et al., 1999; Ferreira et al., 2010; Vilar et al., 2018). Therefore, this work utilized a very promising air-lift bioreactor system. Using these bioreactors, parameters such as initial $\mathrm{pH}$, temperature, contact surface and aeration, which can directly influence the growth of the fungi, consequently improve the expression of enzymes responsible for the degradation process of toxic compounds present in vinasse (Bellettini et al., 2016).

Bioreactors are confined space environments used to promote microbial growth and to perform fermentative processes under controlled physicochemical parameters such as agitation, temperature, $\mathrm{pH}$, aeration, feeding. They are used to promote the synthesis of many bioproducts such as enzymes, antibiotics and organic acids, as well as being applied in the biotreatment of industrial waste (Svojitka et al., 2017; Pino et al., 2018).

Air-lift bioreactors are vessels divided into two main sections: the riser, where the gas is usually injected, and the downcomer, which is parallel to the riser and connected to it at the bottom and at the top; the flow of gas and liquid is downwards. Because of the different gas retention in the riser and the downcomer, the apparent density of the fluid in these zones is different and the liquid circulation is induced. Part of the success of this system is i.e. the relatively constant and low shear characteristics (ideal for lower mechanical strength crops), its simpler design, ease of operation and lower investment and maintenance costs.

The objective of this work was to evaluate the combined effects of temperature and initial $\mathrm{pH}$ on the biodegradation of vinasse and biomass production of Pleurotus sajor-caju CCB020 strain using surface response methodology (RSM) under agitation conditions (mean volume of $0,1 \mathrm{~L}$ ). Experiments were also performed to evaluate the impact of the bioreactor aerial design during the fouling process (mean volume of $7.0 \mathrm{~L}$ ). The main variables and process parameters such as decolorization yield, cell growth, enzyme production and $\mathrm{pH}$ variation were monitored during the experiments. Given the possible applications of the P. sajor-caju enzyme system, the in nature and treated broths were analyzed to quantify the induction of the ligninolytic enzyme complex. 


\section{Material and methods}

\subsection{Microorganisms}

This lignocellulolytic fungus, Pleurotus sajor-caju ССВ020 was obtained from the Laboratory of Applied Ecology of CENA-USP, Piracicaba, SP - Brazil. The fungus was kept in malt extract agar (EMD Chemicals ${ }^{\circledR}$ ) and refrigerated at $4{ }^{\circ} \mathrm{C}$.

\subsection{Conditions for lineage culture}

Three inoculum seeds were aseptically transferred and incubated at $30^{\circ} \mathrm{C}$ for $6-7$ days. The culture medium contained $30.0 \mathrm{~g} / \mathrm{L}$ malt extract, $3.0 \mathrm{~g} / \mathrm{L}$ peptone soybean powder and $15.0 \mathrm{~g} / \mathrm{L}$ agar and was sterilized at $121^{\circ} \mathrm{C}$ for $15 \mathrm{~min}$.

\subsection{Vinasse}

The vinasse was kindly donated by Pinheiro Indústria Sucroalcooleira (Laranjeiras Unit), located in the city of Laranjeiras, SE Brazil ( $10^{\circ} 48^{\prime} 11.39$ 'S, $37^{\circ} 10^{\prime} 10.73^{\prime \prime} \mathrm{W}$ ) during the $2011 / 2012$ harvest season. The vinasse was placed in 5,10 or $20 \mathrm{~L}$ containers and kept refrigerated at $-20{ }^{\circ} \mathrm{C}$ until use. The $\mathrm{pH}$ measured at the collection site was 4.77 units.

\subsection{Culture conditions in experiments with shaker flasks}

The tests were carried out with vinasse under submerged fermentation with P. sajor-caju CCB020 to evaluate the potential of the fungus to decolorize the residue and accumulate biomass during a period of 16 days. For this, three biological replicates were used and the initial temperature $\left(30^{\circ} \mathrm{C}\right)$ and $\mathrm{pH}(5.0)$ of the vinasse medium were recorded during the experiment. The fermentation medium consisted of vinasse adjusted to the desired initial $\mathrm{pH}$ value with $\mathrm{NaOH}(2.5 \mathrm{M})$ or $\mathrm{HCl}(5.0 \mathrm{M})$, without the addition of nutrients, as reported in a previous study (Ferreira et al., 2010). All fermentations were carried out in Erlenmeyer $(250 \mathrm{ml})$ flasks containing $100 \mathrm{ml}$ vinasse, with an initial corrected $\mathrm{pH}$ value. The material was autoclaved at $121^{\circ} \mathrm{C}$ for $15 \mathrm{~min}$. Three plugs $(1.0 \mathrm{~cm}$ in diameter) containing the mycelium of the fungus were inoculated into the culture medium. The flasks were incubated for 16 days in orbital rotation at $180 \mathrm{rpm}$ at different temperatures under low light conditions.

\subsection{Configurations and operating conditions in experiments with air suspension bioreactors}

The conditions of the initial experiment were $30^{\circ} \mathrm{C}$ temperature and $\mathrm{pH} 5.0$ (central points of the experimental design), applied in two different air-lift bioreactors and subsequently evaluated and compared. Both bioreactors used in this work were made of polymethylmethacrylate (Perspex) and equipped with automatic temperature and aeration monitoring.

The first air-suspension bioreactor system used consisted of a concentric tube type air-lift bioreactor with an increased degassing zone (R1), with a total volume of $7 \mathrm{~L}$. The dimensions of the concentric reactor with a raised upper section for degassing are: descent height of $44 \mathrm{~cm}, 7 \mathrm{~cm}$ in diameter; height of the aspiration tube of $41 \mathrm{~cm}$, diameter of $3.2 \mathrm{~cm}$; height of the cylindrical piece of $8 \mathrm{~cm}, 14 \mathrm{~cm}$ in diameter. The angle between the conical sector and the main body was $51^{\circ}$. The gas injection was done through a perforated plate with 5 holes $(0.5 \mathrm{~mm}$ in diameter) placed $2.5 \mathrm{~cm}$ below the riser ring.

The second air suspension bioreactor system consisted of a concentric tube-type air-lift bioreactor without an increased degassing zone (R2). The dimensions of the concentric traction tube type reactor are: $104.0 \mathrm{~cm}$ height, $9.0 \mathrm{~cm}$ diameter; height of the suction tube $72.5 \mathrm{~cm}$, diameter $5.0 \mathrm{~cm}$; height of the cylindrical piece of $15.5 \mathrm{~cm}$ and $3.5 \mathrm{~cm}$ in diameter. Diagrams of the air-lift bioreactors used in this work are shown in Fig. 1. For the initial inoculation in the air-lift bioreactors, the inoculum was first cultured in medium vinasse adjusted to 5.0 initial $\mathrm{pH}$, without the addition of nutrients, in one $\left(30^{\circ} \mathrm{C}, 180 \mathrm{rpm}\right)$ for 10 days. Prior to inoculation, the bioreactor was sterilized using sodium hypochlorite solution ( $2 \%$ active chlorine) 4 days prior to fermentation and then washed with $100 \mathrm{~L}$ of sterile water. Subsequently, the bioreactor was filled with $7 \mathrm{~L}$ of vinasse medium, previously adjusted to 5.0 of the initial $\mathrm{pH}$, and inoculated with $0.6 \mathrm{~L}$ of fungal biomass inoculum in cell suspension. During the experiment, the $\mathrm{pH}$ was monitored and the antifoam solution was used when necessary. The temperature was maintained at $30^{\circ} \mathrm{C}$ by thermostatic bath and the aeration rate adjusted to $1.0 \mathrm{~L} / \mathrm{min}$ by means of a perforated plate at the bottom, thereby promoting efficient diffusion of the air throughout the bioreactor. Samples were collected and analyzed every 24 or 48 h for 16 days.

\subsection{Analytical methods}

The collected samples were vacuum filtered through a filter paper (Whatman $n^{\circ} 1 ; 85$ mm diameter). The dry weight $(\mathrm{g} / \mathrm{L})$ was measured by gravimetry after drying the fungal biomass at $90{ }^{\circ} \mathrm{C}$. The decolorization of the vinasse broth was calculated according to the formula (Eq. (1)) used by Sirianuntapiboon et al. (1995) from absorbance measurements at $475 \mathrm{~nm}$ :

Decolorization $(\%)=[($ initial absorbance

$$
\text { - final absorbance)/initial absorbance]X100 }
$$

The chemical characterization of raw and treated vinasse was performed according to the Standard Methods for Water and Sewage Examination (APHA - American Public Health Association, 1989; Clesceri et al., 2005).

\subsection{Determination of enzymatic activity}

The lignolytic enzymatic activities were determined by spectrophotometer absorbance. Laccase activity was determined at $30{ }^{\circ} \mathrm{C}$ using a mixture containing $0.3 \mathrm{ml}$ of a $0.05 \mathrm{M}$ citrate-
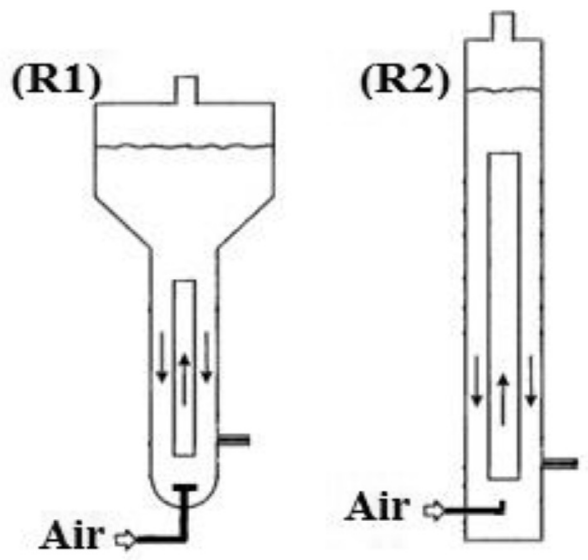

Fig. 1. Schematic diagram of the different air-lift bioreactors used in this work: air-lift bioreactor of the concentric draught tube type with an enlarged degassing zone (R1) and air-lift bioreactor of the concentric draught tube type (R2) without an enlarged degassing. 
phosphate buffer ( $\mathrm{pH} 5.0$ ); $0.1 \mathrm{~mL}$ of $0.05 \mathrm{~g}$ seringaldehyde solution in $50 \mathrm{~mL}$ of ethanol and $0.6 \mathrm{~mL}$ of the crude enzyme supernatant. The oxidation of the siraldaldazine is then measured by monitoring the absorbance at $525 \mathrm{~nm}$ after $10 \mathrm{~min}$ of reaction. One unit of enzyme activity is defined as the amount of enzyme required to oxidize $1.0 \mu \mathrm{L}$ of syringaldazine per minute using the molar extinction coefficient of $6.5 \times 10^{4} / \mathrm{mol} / \mathrm{cm}$ for oxidized syringaldazine. Laccase activity was expressed as enzyme unit per liter of lignocellulolytic (U/L) enzyme extract (Szklarz et al., 1989; Jaroszuk et al., 2018). The activity of manganese-peroxidase (MnP) was determined from the oxidation of phenol red $(610 \mathrm{~nm}=4460 \mathrm{~mol} /$ $\mathrm{cm}$ ) in the presence of manganese and $\mathrm{H}_{2} \mathrm{O}_{2}$ at $30{ }^{\circ} \mathrm{C}$ in a mixture composed of $100 \mu \mathrm{L}$ of sodium lactate buffer $(0.25 \mathrm{~mol} / \mathrm{L}) ; 50 \mu \mathrm{L}$ of a solution of $\mathrm{MnSO}_{4}(2.0 \mathrm{mmol} / \mathrm{L}) ; 50 \mu \mathrm{L}$ of $\mathrm{H}_{2} \mathrm{O}_{2}$ in sodium succinate buffer $(0.2 \mathrm{~mol} / \mathrm{L})$ at $\mathrm{pH} 4.5 ; 200 \mu \mathrm{L}$ of bovine serum albumin $(0.5 \%)$ and $600 \mu \mathrm{L}$ of the crude enzyme extract. The reaction was started with the addition of $100 \mu$ lof phenol red $(0.1 \%)$ and the absorbance measured at $610 \mathrm{~nm} .40 \mu \mathrm{l}$ of $\mathrm{NaOH}(2.0 \mathrm{~N})$ was added as the stop solution after $10 \mathrm{~min}$ following the first reading. A unit of the enzyme activity is defined as the amount of enzyme required to form $1.0 \mu \mathrm{mol}$ of $\mathrm{Mn}^{+3}$ per minute using the molar extinction coefficient of $4.460 \times 103 \mu \mathrm{mol} / \mathrm{cm}$ (Kuwahara et al., 1984). The MnP activity was expressed in enzymatic unit per liter of crude ligninolytic extract $(\mathrm{U} / \mathrm{L})$.

\subsection{Experimental design and optimization by response surface methodology (RSM)}

The experiment was performed using the complete central factorial design $2^{2}$ with temperature and initial $\mathrm{pH}$ factors value at five coded levels, leading to eleven sets of experiments. For the statistical calculation, the variables were coded according to Eq. (2):

$\mathrm{Xi}=(\mathrm{Xi}-\mathrm{X} 0) / \Delta \mathrm{Xi}$

where $\mathrm{xi}$ is the coded value of the independent variable, $\mathrm{Xi}$ is the real value of the independent variable, $X 0$ is the real value of the independent variable in the center point and $\Delta \mathrm{Xi}$ is the real variable change.

The range and levels of the investigated variables are given in Table 1S. Vinasse decolorization $\left(\mathrm{Y}_{1}\right)$ and biomass biosynthesis $\left(\mathrm{Y}_{2}\right)$ were taken as dependent variables or responses of the design experiments; while the independent variables were the initial value of $\mathrm{pH}\left(\mathrm{X}_{1}\right)$ and temperature $\left(\mathrm{X}_{2}\right)$.

The quadratic model for predicting the optimal point was expressed according to Eq. (3):

$\mathrm{Y}_{\mathrm{i}}=\mathrm{b}_{0}+\mathrm{b}_{1} \mathrm{X}_{1}+\mathrm{b}_{2} \mathrm{X}_{2}+\mathrm{b}_{12} \mathrm{X}_{1} \mathrm{X}_{2}+\mathrm{b}_{11} \mathrm{X}_{1}^{2}+\mathrm{b}_{22} \mathrm{X}_{2}^{2}$

where $Y_{i}$ represents the response variable, $b_{0}$ is the intercept coefficient, $b_{1}$ and $b_{2}$ the linear terms, $b_{12}$ the interactive term, $b_{11}$ and $\mathrm{b}_{22}$ the quadratic terms and $\mathrm{X}_{1}$ and $\mathrm{X}_{2}$ represent the studied variables. Whenever possible, the model has been simplified by the elimination of statistically insignificant terms.

The software 'Statistica'(version 8.0) was used for regression and graphical analysis of the obtained data. The statistical significance of the variables was determined by Student's t-test and Fischer's test probability, the equation of the second-order model was determined by the regression coefficients and the proportion of variance explained by the obtained model was given by $\mathrm{R}^{2}$.

\section{Results and discussion}

The first step in the process of searching for optimum conditions is to identify the input variables that influence the response. In a previous work, the effects of different concentrations of sugarcane vinasse and distinct strains of basidiomycete and ascomycete on the capacity of decolorization and accumulation of biomass were investigated (Ferreira et al., 2010). A 100\% vinasse system employing $P$. sajor-caju ССВ020 had the most significant influence on the color removal and degradation of intricate compounds in vinasse. Therefore, this fungus was chosen for further optimization in this expansion process.

\subsection{Cultivation in shake flasks and statistical experiments}

A second order model was fitted for the experimental design $2^{2}$ with axial point configuration $\left( \pm \alpha=2^{1 / 2}\right)$ and three center point repeats. Regression analysis was performed to adjust the decolorization $\left(\mathrm{Y}_{1}\right)$ and biomass biosynthesis $\left(\mathrm{Y}_{2}\right)$ response function with the experimental data (Table $1 \mathrm{~S})$. The equation to predict decolorization $\left(\mathrm{Y}_{1}\right)$ as function of $\mathrm{pH}\left(\mathrm{X}_{1}\right)$ and temperature value $\left(\mathrm{X}_{2}\right)$ is represented to Eq. (4).

$$
\begin{aligned}
Y_{1}= & -1308.342+235.394 X_{1}+56.075 X_{2}-18.375 X_{1}^{2} \\
& -0.922 X_{2}^{2}-1.125 X_{1} X_{2}
\end{aligned}
$$

The statistical significance of the variables envelop in equation of the second order model for decolorization was evaluated by the F-value and associated p-value (Table $2 \mathrm{~S}$ ). It was observed that all the independent variables had a significant influence and that the individual effect of temperature $\left(\mathrm{X}_{1}\right)$ and initial $\mathrm{pH}$ value $\left(\mathrm{X}_{2}\right)$ were positive for this response.

The model did not show a "Lack of fit" relevant and presented a high coefficient of determination $\left(R^{2}=0.94\right)$, confirming the variability of $94 \%$ in the response. The $\mathrm{R}^{2}$ value provides a measure of how much variability in the observed response can be explained by experimental parameters and their interactions, so the model is adequate for statistically optimizing.

The response surface described by model equation $\left(\mathrm{Y}_{1}\right)$ is represented in Fig. 2 (a). The purpose of the response surface methodology was to identify the effect of independent variables large relation to response results. The results of this work, the maximum decolorization (about 93\%) was obtained by working with a temperature of $30{ }^{\circ} \mathrm{C}$ and 5.0 of initial pH as observed in the central point (CP). However, the response surface (Fig. 2 (a)) represented by the second order model for vinasse decolorization showed that $100 \%$ of total decolorization can be achieved at an initial $\mathrm{pH}$ of 5.6 and temperature at $27^{\circ} \mathrm{C}$.

With respect to biomass, only the linear effects of $\mathrm{pH}\left(\mathrm{X}_{1}\right)$ and temperature $\left(X_{2}\right)$ were positive and significant at $95 \%$ confiance (Table 2S). However, to minimize error determination with in the model, quadratic effects were maintained. Consequently, the mathematical model representing the biomass $Y_{2}$ in the experiment can be expressed by Eq. (5).

$$
\begin{aligned}
\mathrm{Y}_{2}= & -70.736+16.96 \mathrm{X}_{1}+2.866 \mathrm{X}_{2}-1.050 \mathrm{X}_{1}^{2}-0.049 \mathrm{X}_{2}^{2} \\
& -0.140 \mathrm{X}_{1} \mathrm{X}_{2}
\end{aligned}
$$

Table $2 \mathrm{~S}$ shows the analysis of variance for the model, variables and interaction, used to evaluate the biomass factor (as a function of temperature and the initial $\mathrm{pH}$ value). The regression is statistically significant $(\mathrm{P}=0.0002)$ at $95 \%$ confiance, representing a high coefficient of determination $\left(R^{2}=0.95\right)$.

The response surface to approximate the biomass production factor $\left(\mathrm{Y}_{2}\right)$ over the independent variables of $\mathrm{pH}\left(\mathrm{X}_{1}\right)$ and temperature $\left(\mathrm{X}_{2}\right)$ is shown in Fig. 2 (b). The maximum biomass production $(12.40 \mathrm{~g} / \mathrm{L})$ was obtained at $25^{\circ} \mathrm{C}$ and initial pH 6.0. However, the response surface adopts that the adjusted model has a true maximum and the coordinates of the maximum point are 

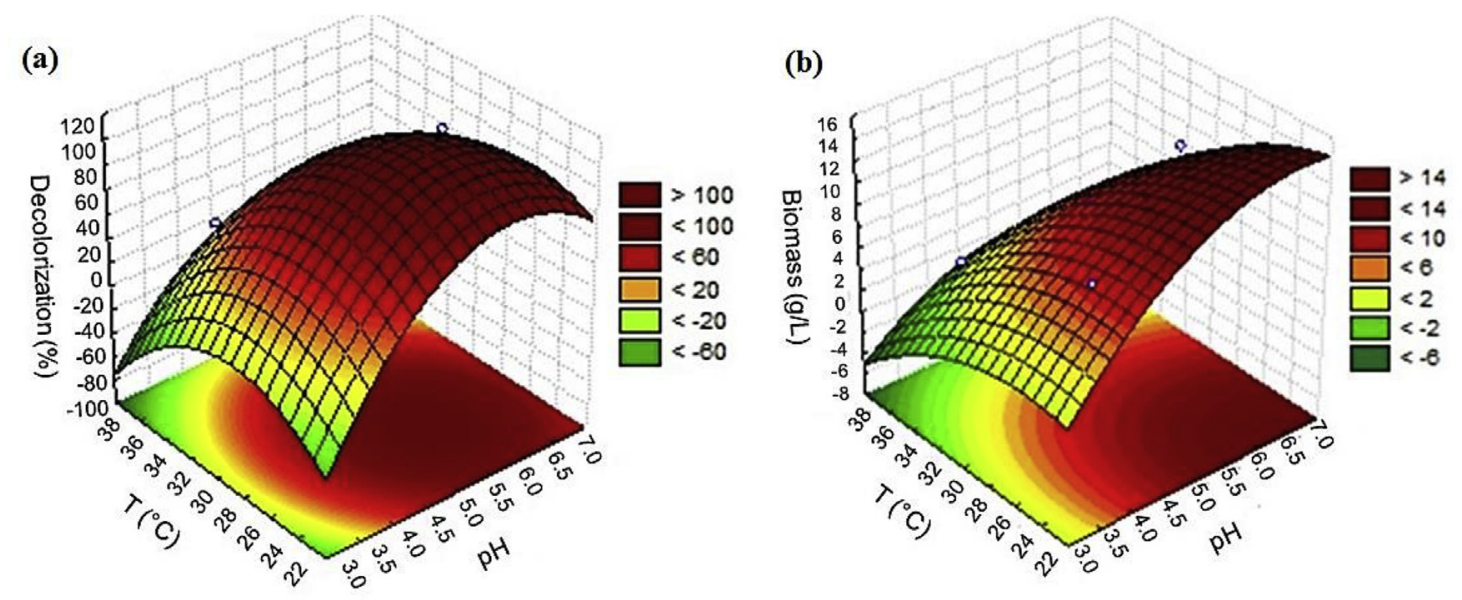

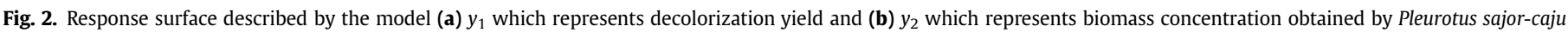
CCB020 during 16 days of cultivation in shake flasks containing sugarcane vinasse medium.

equivalent to the $\mathrm{pH}$ value of 6.8 and the temperature of $20^{\circ} \mathrm{C}$. Under these conditions, the model predicted the maximum production of biomass of $14.37 \mathrm{~g} / \mathrm{L}$.

The fermentative performance in the statistical experiments were also analyzed and compared with the results of the central point, the results of rotating shakers $(100 \mathrm{~mL})$ and experiments in air-lift bioreactors $(7 \mathrm{~L})$. In all cases, the enzymatic activities of laccase and manganese peroxidases were related to decolorization and biomass results.

\subsection{Performance and enzymatic activity studies: Lac and MnP}

According to Fig. 3, fungal growth is directly related to the increase of decolorization in the initial phase of the process, especially when it involves conditions with higher initial $\mathrm{pH}$ values (6.0) and lower temperature values $\left(25^{\circ} \mathrm{C}\right)$. It is possible to identify that in almost all conditions; the average value of decolorization was reached with only 4 days of cultivation. In addition, it was possible to observe that the cultivation of $P$. sajor-caju in $100 \%$ vinasse resulted in a greater amount of biomass than in a medium with diluted vinasse, as well as in the work developed by Ferreira et al. (2010) and Ferreira et al. (2011).

The literature mentions that the production of peroxidases and laccases can be varied according to the species of fungi, as well as carbon and nitrogen sources available in the environment (Paramjeet et al., 2018). Enzyme production (laccase and manganese peroxidase) was correlated to decolorization, biomass production and $\mathrm{pH}$ variation when applied to the conditions of the shake flasks methodology. However, for the analysis in air-lift bioreactors, such results were best achieved when submitted to the initial $\mathrm{pH}$ and core point temperature.

Pleurotus is not able to synthesize lignin peroxidase (LiP), but express laccase, manganese peroxidase, non-dependent $\mathrm{Mn}$ peroxidase, as well as other peroxidases (Knop et al., 2015). This work also investigated the performance of enzymatic activities of laccases and manganese peroxidase as a function of the growth of $P$. sajor-caju in vinasse, under conditions of shake flasks (Fig. 4), showing the peak activity of the laccase after 6 days of fermentation and $\mathrm{MnP}$ after 14 days of fermentation (the experiment lasted 16 days at $30^{\circ} \mathrm{C}$, initial $\mathrm{pH}$ 5.0).

The highest MnP activity was recorded on the 14th day of culture under conditions that could be related to nutritional stress. The activity of laccase and MnP was also evaluated by Ferreira et al. (2010), where the values for MnP were very similar (65 U.L ${ }^{-1}$ ).
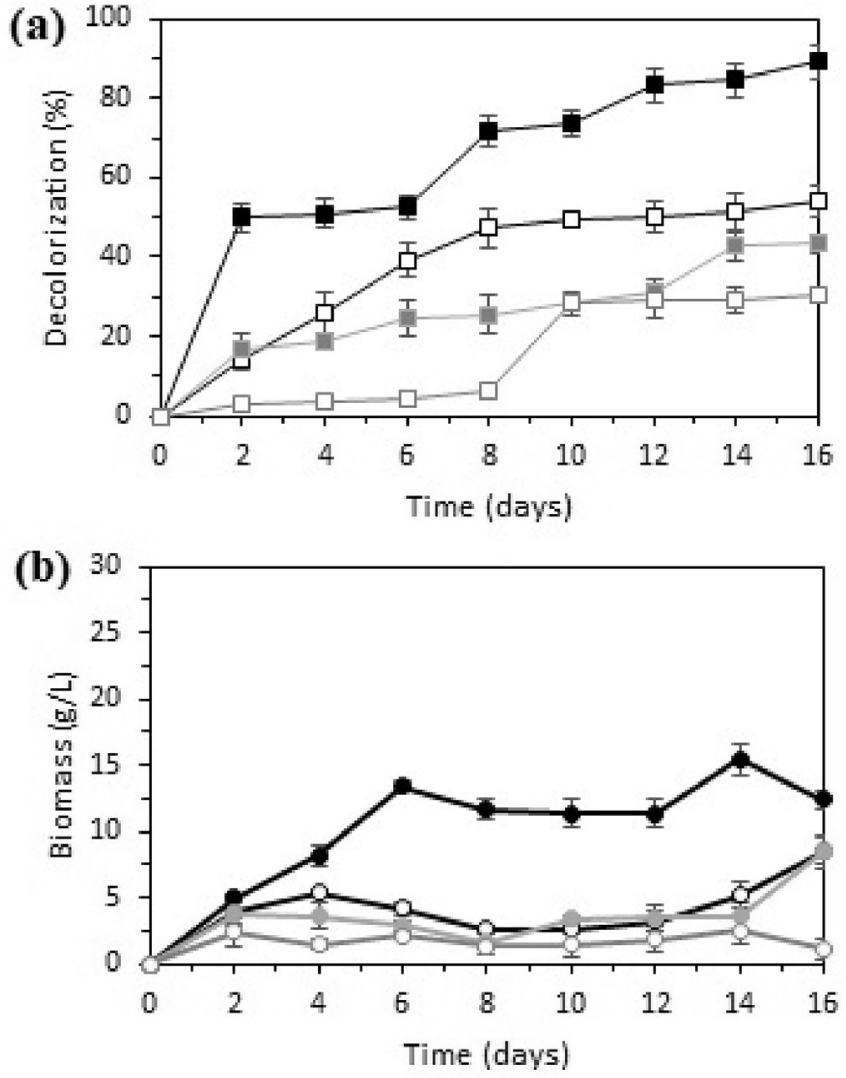

Fig. 3. Decolorization yield (a) and biomass concentration (b) obtained by Pleurotus sajor-caju ССВ020 during 16 days of cultivation in sugarcane vinasse in shake flasks using different cultivation conditions: $25{ }^{\circ} \mathrm{C}$ and initial pH of 6.0 (black line: decolorization $\square$, and biomass 0 ); $35^{\circ} \mathrm{C}$ and initial $\mathrm{pH}$ of 6.0 (black line: decolorization $\square$, and biomass $\mathrm{O}$ ); $25^{\circ} \mathrm{C}$ and initial $\mathrm{pH}$ of 4.0 (grey line: decolorization $\square$, and biomass ๑); $35^{\circ} \mathrm{C}$ and initial pH of 4.0 (grey line: decolorization $\square$, and biomass $\bigcirc$ ).

Manganese peroxidases are the most common ligninases produced by many fungi of white rot and several other common strains. The synthesis of MnP is diffused among different taxonomic groups of basidiomycetes (Hofrichter, 2002). The authors of this work reported that the mechanism of decolorization of melanoidins during the growth of Pleurotus sajor-caju CCB 020 involves primarily the 


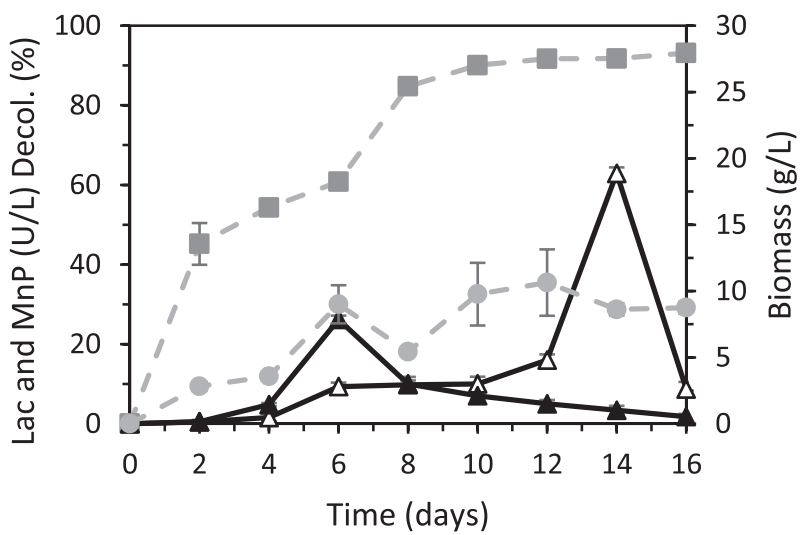

Fig. 4. Decolorization yield (Descol., $\square$ ), biomass concentration (Biomass, ๑), Laccase (Lac, $\boldsymbol{\Delta}$ ) and manganese peroxidase (MnP, $\Delta$ ) activities obtained by Pleurotus sajorcaju ССB020 during 16 days of cultivation at $30{ }^{\circ} \mathrm{C}, 180 \mathrm{rpm}$ and initial pH of 5.0 in shake flasks containg sugarcane vinasse as growth medium.

absorption of melanoidin pigments by mycelial cells and, finally, their intracellular accumulation in the cytoplasm and the cell membrane. Intracellular enzymes act to degrade the melanoidins and are captured by the cells as peroxidase collectors (Sirianuntapiboon et al., 1995; Vilar et al., 2018).

\subsection{Cultivation in different air-lift bioreactors}

To optimise the results of the shake flasks experiments, cultivation in two different air-lift bioreactors was also monitored. The use of two air-lift bioreactors in distinct configurations negates the possibility of interference by altering the gas transfer rate or stirring. With a normal gas-liquid separation in the upper section of the bioreactor, gas retention in the lower corner is insignificant while the liquid flow is maximal. Although in designing good external circuit air-lift reactors, the upper connections between the riser and bottom pipe can be an effective gas-liquid separator, the upper section of the internal reactors should be specially designed for a complete gas-liquid separation. This is accomplished by increasing the cross-sectional area of the lower corner at the top of the reactor. Only a few studies were performed with air-lift reactors with internal circuit and significantly increased gas-liquid separator (Freitas and Teixeira, 1998).

Thus, studies were carried out in different air reactors to validate the performance of vinasse treatment and biomass concentration in scalable equipment and future studies of automatic control of parameters such as aeration and foam levels. Under these conditions, we essayed laccase and manganese peroxidase activities during fermentation and compared them to decolorization yields, biomass concentration and $\mathrm{pH}$ variation.

The decolorization yields of the simple air-lift (R2) and air-lift (with headspace) bioreactors processes (R1) showed similar decolorization profiles (Fig. 5), reaching 68.5\% $( \pm 0.32)$ and $62.0 \%$ $( \pm 0.47)$, respectively, which was significant at level of $5 \%$ of probability. From the profiles observed in Fig. 5, the values reached two plateau (maximum) whatever the bioreactor used: the first was reach between 2 and 5 days and the second between 9 and 12 days. These performances can be explained from the profiles of maximun activities achieved between the enzymes Lac and MnP during vinasse degradation.

It can be observed that Manganese peroxidase (Fig. 6 (a)) and Laccase (Fig. 6 (b)), obtained from the different reactors analyzed, showed similar profiles. However, it was observed that although there was an enzymatic correlation, there was a significant

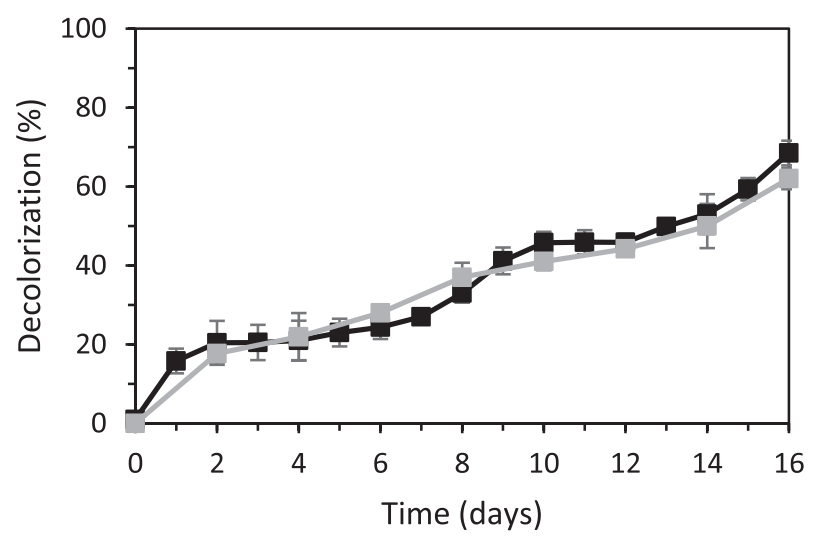

Fig. 5. Decolorization yield obtained using Pleurotus sajor-caju ССВ020 during 16 days of cultivation at $30^{\circ} \mathrm{C}$ and initial $\mathrm{pH}$ of 5.0 in sugarcane vinasse in two different air-lift bioreactors: a simple air-lift bioreactor (grey line: $\square$ ) and a head-space air-lift bioreactor (black line: $\mathbf{\square}$ ).
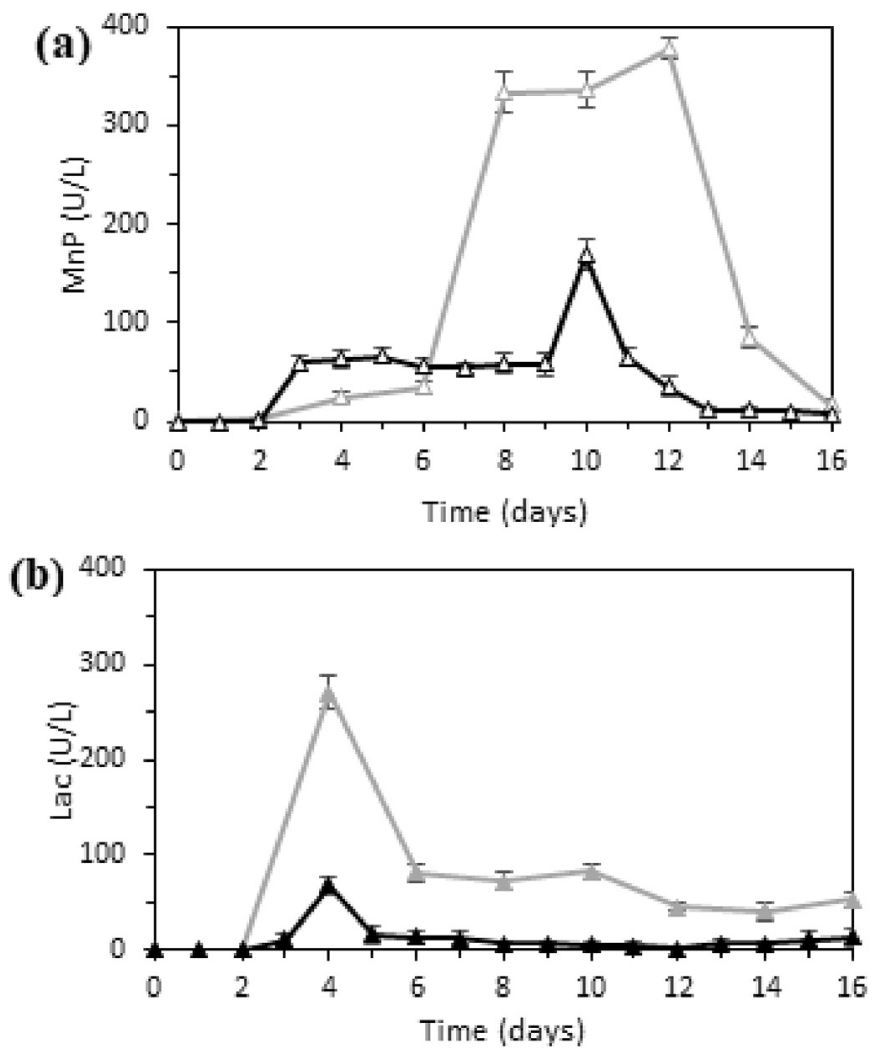

Fig. 6. Manganese peroxidase (MnP)(a) and Laccase (Lac)(b) activities obtained by Pleurotus sajor-caju ССВ020 during 16 days of cultivation at $30{ }^{\circ} \mathrm{C}$ and initial pH of 5.0 in vinasse from sugar-cane molasses under different air-lift bioreactors (black color: head-space air-lift bioreactor, and grey color: simple air-lift bioreactor).

difference in yield values, where the air-lift bioreactor showed more significant values when compared to the air-lift bioreactor in free space. In both processes, the laccase activity was detected on the second day of the experiment, while the peak of its enzymatic activity was evidenced on the fourth day. However, despite the same tendency to be observed in the expression process, the headspace air elevation bioreactor showed a peak of $67.98 \pm 1.04 \mathrm{U} / \mathrm{L}$ (day 4 ), followed by a decrease in activity to $13.02 \pm 0.68 \mathrm{U} / \mathrm{L}$, which was stabilized until the end of the experiment. In the simple air-lift bioreactor, the maximum activity was $269.96 \pm 3.44 \mathrm{U} / \mathrm{L}$ (4th day), 
Table 1

Physicochemical characterization of in natura and treated vinasse.

\begin{tabular}{lll}
\hline Parameters & in natura vinasse & Treated vinasse R1 \\
\hline $\mathrm{pH}\left(20^{\circ} \mathrm{C}\right)$ & $4.77 \pm 0.34$ & $6.2 \pm 0.32$ \\
$\mathrm{COD}(\mathrm{mg} / \mathrm{L})$ & $28100 \pm 980$ & $13300 \pm 620$ \\
$\mathrm{BOD}(\mathrm{mg} / \mathrm{L})$ & $9500 \pm 242$ & $2750 \pm 105$ \\
Total phenols $(\mathrm{mg} / \mathrm{L})$ & $43 \pm 0.34$ & $<0.10$ \\
Total phosphate $(\mathrm{mg} / \mathrm{L})$ & $30 \pm 1.71$ & $20 \pm 1.21$ \\
Total nitrogen $(\mathrm{mg} / \mathrm{L})$ & $338 \pm 10.43$ & $257 \pm 0.94$ \\
Potassium $(\mathrm{mg} / \mathrm{L})$ & $3.23 \pm 0.21$ & $3.5 \pm 0.23$ \\
\hline
\end{tabular}

followed by a first reduction to $79.94 \pm 1.04 \mathrm{U} / \mathrm{L}$, which extended for more six days. After these ten days, activity decreased again, reaching $50.01 \pm 0.73 \mathrm{U} / \mathrm{L}$, which remained stable until the end.

Preliminary shake flask studies using the same fungus strain (P. sajor-caju) and the same culture medium (sugarcane molasses) take a relatively long time (six days) to reach the first peak. After that day, the enzymatic behavior was relatively similar to those obtained in bioreactors, especially when laccase enzyme is observed. These results (Fig. 4) corroborate those obtained in the literature, where the maximum laccase activity was also observed near the sixth day, when submitted to shaken flasks (Ferreira et al., 2010). However, from this slight comparison, it was possible to observe that although there is a correlation regarding the enzymatic productivity profile, the values obtained by the bioreactors are higher than the shake flasks.

In the case of MnP, the profile obtained in the simple air-lift bioreactor also presented higher enzymatic activities, in addition to maintaining the peak of MnP activity longer. Thus, in Fig. 6 (a), it can be observed that the maximum MnP activity in the head-space air-lift bioreactor was detected on the tenth day $(167.61 \pm 2.74 \mathrm{U} / \mathrm{L})$, followed by a decrease. which reached $8.04 \pm 0.21 \mathrm{U} / \mathrm{L}$ on the sixteenth day. In the simple air-lift bioreactor (Fig. 6 (a)), the peak activity of MnP was sustained for approximately 5 days. However, the most significant point was only reached on the twelfth day, with an average value of $350.42 \pm 3.50 \mathrm{U} / \mathrm{L}$, decreasing to $6.10 \pm 0.25 \mathrm{U} / \mathrm{L}$ on the sixteenth day. In studies conducted on shake flasks in the same culture medium (sugarcane vinasse), we observed that P. sajor-caju takes a relatively long time (fourteen days) to reach its maximum activity (Fig. 5). Thus, it is possible to highlight that the use of bioreactors may favor the induction of the activity of this enzyme in advance.

It should be noted that the activities obtained when the experiments were performed in shake flasks were lower than the results obtained in air-lift bioreactors. This difference seems to be dependent on the type of configuration of the bioreactor. When obtained in R1, the values were approximately 3 times higher for laccase $(26.21 \pm 1.94 \mathrm{U} / \mathrm{L}$ in $\mathrm{CP}$ shake flasks and $67.32 \pm 1.34 \mathrm{U} / \mathrm{L}$ in the R1 air lifting bioreactor) and 10 times higher for $\mathrm{MnP}$ $(25.66 \pm 0.54$ in $\mathrm{CP}$ shake flasks and $66.60 \pm 1.69 \mathrm{U} / \mathrm{L}$ in the $\mathrm{R} 1$ air lifting bioreactor). When obtained in R2, the values were approximately 3 times higher for laccase $(26.21 \pm 1.94 \mathrm{U} / \mathrm{L}$ in CP shake flasks and $67.32 \pm 1.34 \mathrm{U} / \mathrm{L}$ in the $\mathrm{R} 1$ air lifting bioreactor) and 6 times higher for $\mathrm{MnP}(25.66 \pm 0.54 \mathrm{U} / \mathrm{L}$ in $\mathrm{CP}$ shake flasks and $66.60 \pm 1.69 \mathrm{U} / \mathrm{L}$ in the R1 air lifting bioreactor).

Although the air-lifts system provided greater activity for laccase and manganese enzymes, these values were not sufficient to achieve decolorization levels equals to or greater than those observed in the method using shake flasks $(94.12 \pm 1.38 \%$ in shaker flasks CP and $68.50 \% \pm 0.32$ in the $\mathrm{R} 1$ air-lift bioreactor and $62.07 \% \pm 0.47$ in the air-lift bioreactor R2). If we consider only the decolorization obtained between bioreactors, we can observe the highest values of decolorization in the experiment with lower levels of activity. This behavior probably occurred due to differences in bioreactor configurations, mainly because this difference caused a change in the hydrodynamic behavior of the bioprocesses. Table 1 presents the chemical characterization of nature and treated vinasse, when in experiments with bioreactors. The incubation of $P$. sajor-caju in vinasse, under conditions of air bioreactor, resulted in a great reduction in chemical oxygen demand (53.05\% for R1 and 58.34\% for R2) and biological oxygen demand $(71.40 \%$ for $\mathrm{R} 1$ and $58.01 \%$ for $\mathrm{R} 2$ ) under submerged fermentation conditions after incubation at $30{ }^{\circ} \mathrm{C}$ for 16 days. Ferreira et al. (2011) obtained similar values and in their study of sugarcane vinasse also treated with Pleurotus sajor-caju, with these results obtained in shake flasks. The treatment of vinasse with $P$. sajor-caju ССВ020 also resulted in changes in the physical-chemical characteristics when compared to vinasse before treatment of biodegradation with the fungus (Table 1 ). There was a reduction in many analyzed parameters: phenols ( $\geq 99 \%)$, total phosphate as $\mathrm{P}$ (33\% for R1 and $67 \%$ for R2) and total nitrogen (24\% for R1 and $35 \%$ for R2). The amount of potassium presented a smaller increase ( $10 \%)$ when compared to raw vinasse. The potassium determination was permormed by flame photometry. From this method, chemical interferences may occur when the concentration of certain ions $\left(\mathrm{NH}^{4+}, \mathrm{Na}^{+}, \mathrm{Ca}^{+2}, \mathrm{Cl}^{-}, \mathrm{PO}_{4}^{-3}, \mathrm{SO}_{4}^{-2}\right.$, etc.) is high in solution. The Standard Methods for the Examination of Water and Wastewater (APHA - American Public Health Association, 1989) reports that the interference in the potassium determination occurs when the proportions of sodium to potassium are 5:1 or greater. Specifically, in the present study, the potassium concentration found in the treated vinasse by the air-lift bioreactors (R1 and R2) was a little higher than the vinasse in natura. Thus, the high sodium:potassium ratio found in treated vinasse in both bioreactors, due to $\mathrm{NaOH}$ contribution to increasing $\mathrm{pH}$, promotes interference in the direct measure of potassium in the solution, thanks to the high amount of $\mathrm{Na}^{+}$, as occurred in the work proposed by Vilar et al. (2018).

\section{Conclusion}

From the obtained results, a high percentage of vinasse decolorization and fungal biomass production were found studying the central point $\left(30^{\circ} \mathrm{C}\right.$ and $\mathrm{pH}$ 5.0) of mycoremediation in shake flasks with the basidiomycete fungus $P$. sajor-caju CCB 020. These preliminary studies indicated the importance of the selected fungus with a potential for vinasse decolorization in air-lift bioreactors. When comparing to the air-lift bioreactor (with headspace - R1), the simple air-lift bioreactor (without headspace - R2) was substantially more effective to induce Lac and MnP enzymes, which could be explained by the circulation homogeneity inside the system. Furthermore, an interference in physicochemical performance was observed comparing the configuration of the bioreactors tested.

Moreover, the air-lift bioreactors perform well next to the optimized conditions (raw vinasse at $30{ }^{\circ} \mathrm{C}$ and $\mathrm{pH}$ 5.0) when compared to flasks. They have the potential to extend studies for 
future sucroenergetic sector applications of raw vinasse, as well as the production of enzymes for biotechnological use (Lac and MnP) and edible biomass for aquaculture practice. This also aggregates an environmental and economical value to a residue easily accessible and affordable for biorefinery processes.

\section{Declaration of competing interest}

I have read and have abided by the statement of ethical standards for manuscripts submitted to Chemosphere, as well as the other statement that all authors have approved the final article. The authors declare to have materially participated in paper "Mycoremediation of vinasse by surface response methodology and preliminary studies in air-lift bioreactors" and are represented by the corresponding author Luiz Fernando Romanholo Ferreira. Furthermore, the authors declare no conflict of interest and agree with submission of the revised manuscript to Chemosphere.

\section{Acknowledgments}

The authors acknowledge financial assistance from the Brazilian research funding agencies as CAPES (Coordination for the Improvement of Higher Education Personnel) under Finance Code 001, a Brazilian foundation within the Ministry of Education (MEC), CNPq (National Council for Scientific and Technological Development; grant number 421147/2016-4; 311264/2017-4; 315247/20185 and 315405/2018-0), a Brazilian foundation associated to the Ministry of Science and Technology (MCT), FAPITEC/SE (the Foundation of Support to Research and Technological Innovation of the State of Sergipe) and by Bioexx Applied Technology.

\section{Appendix A. Supplementary data}

Supplementary data to this article can be found online at https://doi.org/10.1016/j.chemosphere.2019.125432.

\section{References}

Alcalde, M., 2015. Engineering the ligninolytic enzyme consortium. Trends Biotechnol. 33, 155-162.

APHA - American Public Health Association, 1989. Standard Methods for the Examination of Water and Wastewater, seventeenth ed. American water works association, water environmental federation, Washington, DC.

Bellettini, M.B., Fiorda, F.A., Maieves, H.A., Teixeira, G.L., Ávila, S., Hornung, P.S., Júnior, A.M., 2016. Factors affecting mushroom Pleurotus spp. Saudi J. Biol. Sci. 8, 489-496.

Borja, R., Martín, A., Maestro, R., Luque, M., Durán, M.M., 1993. Improvement of the kinetics of anaerobic digestion of molasses by the removal of phenolic compounds. J. Appl. Chem. Biotechnol. 35, 517-528.

Calvo, A.M., Copa-Patino, J.L., Alonso, O., Gonzalez, A.E., 1998. Studies of the production and characterization of laccase activity in the basidiomycete Coriolopsis gallica, an efficient decolorizer of alkaline effluents. Arch. Microbiol. 171, 31-36.

Chanakya, H.N., Malayil, S., Vijayalakshmi, C., 2015. Cultivation of Pleurotus spp. on a combination of anaerobically digested plant material and various agro-residues. Energy Sustain. Dev. 27, 84-92.

Clesceri, L.S., Eaton, A.D., Greenberg, A.E., Rice, E.W., 2005. Standard Methods for the Water and Wastewater -, Centennial twenty-first ed. ${ }^{\mathrm{a}}$ Ed.

Colin, V.L., Cortes, A.A.J., Aparicio, J.D., Amoroso, M.J., 2016. Potential application of a bioemulsifier-producing actinobacterium for treatment of vinasse. Chemosphere $144,842-847$.

Corrêa, R.C.G., Brugnari, T., Bracht, A., Peralta, R.M., Ferreira, I.C.F.R., 2016. Biotechnological, nutritional and therapeutic uses of Pleurotus spp. (Oyster mushroom) related with its chemical composition: a review on the past decade findings. Trends Food Sci. Technol. 50, 103-117.

Ferreira, L.F., Aguiar, M., Pompeu, G., Messias, T.G., Monteiro, R.R., 2010. Selection of Vinasse degrading microorganisms. World J. Microbiol. Biotechnol. 26, 1613-1621.

Ferreira, L.F.R., Aguiar, M.M., Messias, T.G., Pompeu, G.B., Queijeiro, L.A.M., Silva, D.P., Monteiro, R.T., 2011. Evaluation of sugar-cane vinasse treated with Pleurotus sajor-caju utilizing aquatic organisms as toxicological indicators. Ecotoxicol. Environ. Saf. 74, 132-137.

Finimundy, T.C., Barros, L., Calhelha, R.C., Alves, M.J., Prieto, M.A., Abreu, R.M.V., Dillon, A.J.P., Henriques, J.A.P., Ely, M.R., Ferreira, I.C.F.R., 2018. Multifunction of
Pleurotus sajor-caju (Fr.) Singer: a highly nutritious food and a source for bioactive compounds. Food Chem. 245, 150-158.

Freitas, C., Teixeira, J.A., 1998. Hydrodynamic studies in an air-lift reactor with an enlarged degassing zone. Bioprocess Eng. 18, 267-279.

González, T., Terrón, M.C., Yagüe, S., Junca, J., Carbajo, J.M., Zapico, E.J., Silva, R., Cuenca, A.A., Téllez, A., González, A.E., 2008. Melanoidin-containing wastewaters induce selective laccase gene expression in the white-rot fungus Trametes sp. I-62. Res. Microbiol. ume 159 (2), 103-109. March 008.

Guerreiro, L.F., Rodrigue, C.S.D., Duda, R.M., Oliveira, R.A., Boaventura, R.A.R. Madeira, L.M., 2016. Treatment of sugarcane vinasse by combination of coagulation/flocculation and Fenton's oxidation. J. Environ. Manag. 181, 237-248.

Hoarau, J., Grondin, I., Caro, Y., Petit, T., 2018. Sugarcane distillery spent wash, a new resource for third-generation biodiesel production. Water 10 (11), 1623.

Hofrichter, M., 2002. Review: lignin conversion by manganese peroxidase (MnP). Enzym. Microb. Technol. 30, 454-466.

Jaroszuk, M.O., Jaszek, M., Starosielec, M., Sulej, J., Matuszewska, A., Janczarek, M., Bancerz, R., Wydrych, J., Wiater, A., Wilkołazka, A.J., 2018. Bacterial exopolysaccharides as a modern biotechnological tool for modification of fungal laccase properties and metal ion binding. Bioproc. Biosyst. Eng. 41, 973-989.

Knop, D., Yarden, O., Hadar, Y., 2015. The ligninolytic peroxidases in the genus Pleurotus: divergence in activities, expression, and potential applications. Appl. Microbiol. Biotechnol. 99, 1025-1038.

Krzywonos, M., Seruga, P., 2012. Decolorization of sugar beet molasses vinasse, a high-strength distillery wastewater, by lactic acid bacteria. Pol. J. Environ. Stud. 21, 943-948.

Krzywonos, M., Chalupniak, A., Swiatek, M.Z., 2017. Decolorization of beet molasses vinasse by Bacillus megaterium ATCC 14581. Ann. Finance 21, 81-88.

Kuwahara, M., Glenn, J.K., Morgan, M.A., Gold, M.H., 1984. Separation and characterization of two extracellular $\mathrm{H} 2 \mathrm{O} 2$ dependent oxidases from lignolytic cultures of Phanerochaetechrysosporium. FEMS Microbiol. Lett. 169, 247-250.

Liu, L., Lin, Z., Zheng, T., Lin, L., Zheng, C., Lin, Z., 2009. Fermentation optimization and characterization of the laccase from Pleurotus ostreatus strain 10969. Enzym. Microb. Technol. 44, 26-33.

Menezes, D.B., Brazil, O.A.V., Ferreira, L.F.R., Polizeli, M.L.T.M., Ruzene, D.S. Silva, D.P., Costa, L.P., Macedo, M.L.H., 2017. Prospecting fungal ligninases using corncob lignocellulosic Fractions. Cellulose 24, 4355-4365.

Moraes, B.S., Zaiat, M., Bonomi, A., 2015. Anaerobic digestion of vinasse from sugarcane ethanol production in Brazil: challenges and perspectives. Renew. Sustain. Energy Rev. 44, 888-903.

Munari, F.M., Gaio, T.A., Calloni, R., Dillon, A.J.P., 2008. Decolorization of textile dyes by enzymatic extract and submerged cultures of Pleurotus sajor-caju. World J. Microbiol. Biotechnol. 24, 1383-1392.

Owaid, M.N., Abed, I.A., Al-Saeedi, S.S.S., 2017. Applicable properties of the biofertilizer spent mushroom substrate in organic systems as a byproduct from the cultivation of Pleurotus spp. Inf. Process. Agric. 4, 78-82.

Paramjeet, S., Manasa, P., Korrapati, N., 2018. Biofuels: production of fungalmediated ligninolytic enzymes and the modes of bioprocesses utilizing agrobased residues. Biocatal. Agric. Biotechnol. 14, 57-71.

Pino, M.S., Jasso, R.M.R., Michelin, M., Gallegos, A.C.F., Rodriguez, R.M., Teixeira, J.A., Ruiz, H.A., 2018. Bioreactor design for enzymatic hydrolysis of biomass under the biorefinery concept. Chem. Eng. J. 347, 119-136.

Queiroga, J.A., Souza, D.F., Nunes, E.H., Silva, A.F., Amaral, M.C.S., Ciminelli, V.S.T. Vasconcelos, W.L., 2018. Preparation of alumina tubular membranes for treating sugarcane vinasse obtained in ethanol production. Separ. Purif. Technol. 190, 195-201.

Rodríguez, E., Pickard, M., Vazquez-Duhalt, R., 1999. Industrial dye decolorization by laccases from ligninolytic fungi. Curr. Microbiol. 38, 27-31.

Rouches, E., Herpoël-Gimbert, I., Steyer, J.P., Carrere, H., 2016. Improvement of anaerobic degradation by white-rot fungi pretreatment of lignocellulosic biomass: a review. Renew. Sustain. Energy Rev. 59, 179-198.

Santal, A.R., Singh, N.P., Saharan, B.S., 2016. A novel application of Paracoccus pantotrophus for the decolorization of melanoidins from distillery effluent under static conditions. J. Environ. Manag. 169, 78-83.

Seruga, P., Krzywonos, M., 2015. Screening of medium components and process parameters for sugar beet molasses vinasse decolorization by Lactobacillus plantarum using placket-burman experimental design. Pol. J. Environ. Stud. 24, 683-688.

Silveira, M.L.L., Smiderle, F.R., Agostini, F., Pereira, E.M., Bonatti-Chaves, M., Wisbeck, E., Ruthes, A.C., Sassaki, G.L., 2015. Exopolysaccharide produced by Pleurotus sajor-caju: its chemical structure and anti-inflammatory activity. Int. J. Biol. Macromol. 75, 90-96.

Sirianuntapiboon, S., Sihanonth, P., Somchai, P., Atthasampunna, P., Hayashida, S. 1995. An adsorption mechanism for melanoidin decolorization by Rhizoctonia sp. Biosci. Biotechnol. Biochem. 59, 1185-1189.

Souza, R.P., Ferrari-Lima, A.M., Pezoti, O., Santana, V.S., Gimenes, M.L., FernandesMachado, N.R.C., 2016. Photodegradation of sugarcane vinasse: evaluation of the effect of vinasse pre-treatment and the crystalline phase of TiO2. Acta Sci. Technol. 38, 217-226.

Svojitka, J., Dvořák, L., Studer, M., Straub, J.O., Frömelt, H., Wintgens, T., 2017. Performance of an anaerobic membrane bioreactor for pharmaceutical wastewater treatment. Bioresour. Technol. 229, 180-189.

Szklarz, G., Antibus, R.K., Sinsabaugh, R.L., Linkins, A.E., 1989. Production of phenoloxidases and peroxidases by wood-rotting fungi. Mycologia 81, 234-240.

Tarhan, L., Tongul, B., 2017. The induction of ligninolytic enzymes depending on menadione based oxidative stress and cell damages in Phanerochaete 
chrysosporium. Int. Biodeterior. Biodegrad. 117, 1-7.

Tostain, G.C., Hoarau, J., Watson, M., Adelard, L., Sing, A.S.C., Caro, Y., Grondin, I, Bourven, I., Francois, J.M., Neuhauser, E.G., Petit, T., 2018. Production of Aspergillus Niger biomass on sugarcane distillery wastewater: physiological aspects and potential for biodiesel production. Fungal Biol.Biotechnol. 5 (1)

Vilar, D.S., Carvalho, G.O., Pupo, M.M.S., Aguiar, M.M., Torres, N.H., Américo, J.H.P.,
Cavalcanti, E.B., Eguiluz, K.I.B., Banda, G.R.S., Leite, M.S., Ferreira, L.F.R., 2018. Vinasse degradation using Pleurotus sajor-caju in a combined biological electrochemical oxidation treatment. Separ. Purif. Technol. 192, 287-296.

Voběrková, S., Solčány, V., Vršanská, M., Adam, V., 2018. Immobilization of ligninolytic enzymes from white-rot fungi in cross-linked aggregates. Chemosphere 202, 694-707. 